\title{
Characterization and identification of mannanolytic actinomycete Nonomuraea sp. ID06-379
}

\author{
Shanti Ratnakomala ${ }^{1,2}$, Yopi $^{2}$, Bambang Prasetya ${ }^{2,5}$, Maggy Thenawidjaja Suhartono ${ }^{3}$ and Anja Meryandini ${ }^{4}$ \\ ${ }^{1}$ Major Microbiology, Graduate School Bogor Agricultural University, Bogor, Indonesia. \\ ${ }^{2}$ Research Center for Biotechnology, Indonesian Institute of Sciences (LIPI), Indonesia. \\ ${ }^{3}$ Department of Food Science and Technology, Faculty of Agricultural Engineering and Technology, \\ Bogor Agricultural University, Bogor, Indonesia. \\ ${ }^{4}$ Department of Biology, Faculty of Mathematics and Natural Sciences, Bogor Agricultural University, Bogor, Indonesia. \\ ${ }^{5}$ National Standardization Agency, Jakarta, Indonesia. \\ Email:ameryandini@yahoo.com
}

Received 4 August 2014; Received in revised form 3 March 2015; Accepted 2 April 2015

\begin{abstract}
Aims: The study focused on screening, identification and characterization of mannanolytic actinomycetes isolated from soil and leaf litter samples obtained from several sites in Indonesia.

Methodology and results: A total of 337 isolates of actinomycetes isolated from soil and leaf litter samples collected from various areas in Indonesia were screened for their mannanolytic activity. Mannanase activity was analysed using locus bean gum (LBG) as the substrate. The strain ID06-0379 displayed significant mannanase activity. The strain ID060379 was analysed for its mannanase activity by determining the rate of enzyme production when cultured in the presence of palm kernel cake (PKC) as a substrate. The highest mannanase activity from ID06-0379 was $4.40 \mathrm{U} / \mathrm{mL}$ at $5 \%$ PKC concentration at 5 days incubation. Chemotaxonomic and phenotypic characterisation of mannanolytic actinomycete was done and the strain ID06-0379 contained meso-diaminopimelic acid, and madurose was the diagnostic sugar in whole cell sugar. The polar lipids were phosphatidylethanolamine, diphosphatidylglycerol, phosphatidylinositol, and hydroxy-phosphatidylethanolamine. The predominant menaquinone of strain ID06-0379 was MK-9 $\left(\mathrm{H}_{4}\right)$. The major cellular fatty acids were $\mathrm{C}_{16: 0}(31.47 \%)$, cis9- $\mathrm{C}_{16: 1}(15.23 \%)$ and iso- $\mathrm{C}_{16: 0}(10.84 \%)$, and the $\mathrm{G}+\mathrm{C}$ content of the DNA was $71.7 \mathrm{~mol} \%$. Phylogenetic analysis based on the 16S rDNA sequences revealed that strain ID06379 was closely related to species of Nonomuraea jabiensis A4036T with $99 \%$ nucleotide similarity.

Conclusion, significance and impact study: The results from this study revealed that the mannanolytic actinomycete strain ID06-379 belongs to the genus Nonomuraea that closely related to $N$. jabiensis $A 4036^{\top}$. Mannanase production using agricultural waste such as palm kernel cake may contribute to the development and utilisation of biomass bioconversion processes.
\end{abstract}

Keywords: Indonesian actinomycetes, mannanase enzyme, locus bean gum, palm kernel cake, Nonomuraea sp. ID060379.

\section{INTRODUCTION}

Plant cell walls consist of complex polymers which are mainly cellulose, hemicellulose and lignin. Hemicellulose is the second major component of the plant cell wall and the most abundant and renewable carbohydrate consists mainly of mannan and xylan (Lynd et al., 2002). Hemicellulose is a matrix polysaccharide that constitutes up to $50 \%$ of lignocellulosic biomass depending on the source. Lignocellulose degradation in the natural environment is largely attributed to fungi, and the importance of actinomycetes in this process may be underestimated. The production of $\beta$-mannanase by microorganisms is more promising due to its low cost, high production rate and readily controlled conditions (Meenakshi et al., 2010).

Microbial mannanases are the primary endo-type enzymes responsible for degradation of mannan polysaccharides (Kim et al., 2011). Mannanases have been isolated from Aspergillus spp. (Azis et al., 2008), Penicilliumfreii (Wang et al., 2012), Chaetomium sp. (Katrolia et al., 2012), Bacillus pumilus, Caldicellosiruptor saccharolyticus (Frangos et al., 1999); Cellulosimicrobium sp. (Kim et al., 2011) and B. subtilis (Bo et al., 2009). Thermomonospora fusca was also reported to secrete thermostable $\beta$-mannanase at temperature of $80{ }^{\circ} \mathrm{C}$, which hydrolyses the O-glycosidic bonds in mannan, and

\section{*Corresponding author}


has potential use in pulp and paper production (Béki et al., 2003).

It is well-known that the cellulolytic actinomycetes include members of the genera Cellulomonas and that Themomonospora fusca can also produce mannanase enzymes (Béki et al., 2003). In the genus Streptomyces, mannan-degrading activity has been found in some strains (Yopi et al., 2006; Shi et al., 2011; Kumagai et al., 2012). Degradation of mannan is a key step in the production of bioethanol from palm kernel cake (PKC) material, as mannan constitutes $78 \%$ of PKC biomass (Wong et al., 2011). Structurally, mannan is composed of mannose backbone that is linked to various sugar moieties, such as galactose. Actinomycetes genera such as Streptomyces, Nocardia, Arthrobacter and Rhodococus produce hemicellulases, cellulases and lignases, all of which play an important role in lignocellulose degradation (Khanderparker et al., 2008). The hydrolysis of hemicellulose by hemicellulases is important in biofuel production as this polysaccharide is widely distributed throughout the lignocellulosic structure and contains a large amount of fermentable sugars.

In this study, we screened actinomycetes from our existing collection for their capability to produce mannanase enzyme. The actinomycete was isolated from rhizosphere soil and leaf litter samples obtained from several sites in Indonesia (Widyastuti and Ando, 2009; Lisdiyanti et al., 2012). Evaluation of the production of mannanase enzyme from mannanolytic actinomycetes using palm kernel cake as a substrate was also performed. This study may contribute to the development and utilisation of biomass bioconversion processes.

\section{MATERIALS AND METHODS}

\section{Actinomycetes isolates}

A total of 337 actinomycetes isolates collected from Purwodadi Botanical Garden, Bukit Sari Botanical Garden Jambi, Cibinong in West Java, Enrekang in South Sulawesi, Timor East Nusa Tenggara, Kutai National Park in East Kalimantan, Gili and Kuta in Lombok Island, Sungai Wain Botanical Garden, Baturraden Botanical Garden, Bantimurung South Sulawesi, and Papua, Indonesia were used in this study. The actinomycetes were isolated from rhizosphere soil and leaf litter samples and all the isolates were identified based on 16S rDNA sequences (Widyastuti and Ando, 2009).

\section{Selection of mannanase-producing actinomycetes}

All 337 isolates were cultured on Locus Bean Gum (LBG agar) medium containing $0.4 \%$ yeast extract, $0.4 \%$ malt extract, and $0.5 \%$ LBG $(\mathrm{pH} 7.0)$. Isolates were cultured onto LBG agar plates and incubated for 4 days at $28^{\circ} \mathrm{C}$. Plates were then flooded with $0.1 \%$ Congo red for $15-20$ min, then washed with $1 \mathrm{mM} \mathrm{NaCl}$, and kept overnight at 5 ${ }^{\circ} \mathrm{C}$. Bacterial colonies exhibiting clear zones against red colour of non-hydrolysed media were considered mannanase producers (Carder, 1986).
Mannanase production was indicated by the appearance of a pale halo with orange edges, indicative of areas of hydrolysis. This halo was measured for the subsequent calculation of the enzymatic clear zone index (CZI) using the equation:

$$
\mathrm{CZI}=\frac{\text { diameter of hydrolysis zone }}{\text { diameter of colony }}
$$

\section{Mannanase activity assay}

ß-Mannanase activity of strain ID06-379 was determined by monitoring the release of reducing sugars. Mannanase activity was measured following the dinitrosalicylic acid (DNS) method of Miller (1959). Briefly, a reaction mixture composed of $0.1 \mathrm{~mL}$ of crude enzyme solution plus 0.9 $\mathrm{mL}$ of $0.5 \%$ LBG in $50 \mathrm{mM}$ sodium citrate buffer $(\mathrm{pH} 6.0)$ was incubated at $50{ }^{\circ} \mathrm{C}$ in a water bath for $30 \mathrm{~min}$. The reaction was terminated by adding $2 \mathrm{~mL}$ of DNS reagent. The colour was then developed by boiling the mixture for 15 min. Optical densities of samples were measured at $540 \mathrm{~nm}$ against a blank containing all the reagents minus the crude enzyme. Results were interpreted in terms of enzyme activity in which one unit $(U)$ of enzyme activity was defined as the amount of enzyme which liberates 1 $\mu \mathrm{mol}$ of glucose per minute under the given assay conditions (Miller, 1959).

\section{Extracellular enzyme production}

The strain ID06-379 was grown in the medium for mannanase production which contained $0.4 \%$ yeast extract, $1 \%$ malt extract, and $0.4 \%$ locust bean gum $(\mathrm{pH}$ 7.3). A $250 \mathrm{~mL}$ flask containing $50 \mathrm{~mL}$ of the medium was inoculated with a loopful of cells taken from a stock slant and was pre-cultured at room temperature on a shaker (120 rpm) for 3 days. The same volume of medium and flasks for enzyme production were inoculated with $5 \mathrm{~mL}$ of the culture and cultivated at room temperature for 8 days. Aliquots of the culture medium were sampled at 1 day intervals to determine $\beta$-mannanase activity.

\section{Enzyme production under submerged fermentation with palm kernel cake as substrate}

The strain ID06-379 was grown under submerged fermentation by taking $25 \mathrm{~mL}$ of submerged fermentation medium containing yeast extract $0.4 \%$, malt extract $1 \%$ and glucose was substituted with agricultural substrates i.e. palm kernel cake at $1 \%, 5 \%$ and $10 \%$ concentrations in $100 \mathrm{~mL}$ erlenmeyer flasks. All flasks were autoclaved at $121^{\circ} \mathrm{C}$ for $20 \mathrm{~min}$ then cooled to room temperature. After cooling, media were inoculated with $10 \%$ of bacterial inoculum pre-grown for 3 days. Flasks containing inoculated media were incubated at room temperature on a rotary shaker at $120 \mathrm{rpm}$. Submerged fermentation was conducted for six days using a set of three flasks for each substrate used. Enzyme production was achieved under submerged fermentation; $3 \mathrm{~mL}$ culture was sampled at 1 
day intervals and the fermented matter was processed, as described above.

\section{Phylogenetic analysis of strain ID06-379 based on 16S rDNA}

DNA was isolated using PrepMan ${ }^{\circledR}$ Ultra Reagent (Applied Biosystems) according to the manufacturer's instruction. 16S rRNA gene was amplified by PCR using KOD FX (Toyobo) with the following pair of primers: 9F (5'GAGTTTGATCCTGGCTCAG) and 1541R (5'AAGGAGGTGATCCAGCC). The amplified 16S rRNA gene was subjected to cycle sequencing using a BigDye Terminator v3.1 Cycle Sequencing Kit (Applied Biosystems) with the following primers: 9F, 785F (5'GGATTAGATACCCTGGTAGTC), 802R (5'TACCAGGGTATCTAATCC) and 1541R. The products were analysed using an automated DNA sequencer ( $A B$ PRISM 3730 Genetic Analyzer; Applied Biosystems).

The phylogenetic neighbours were identified and pairwise 16S rRNA gene sequence similarities were calculated, using the EzTaxon-e server (Kim et al., 2012). The CLUSTAL_X program (Thompson et al., 1997) was used to align the almost-complete 16S rRNA gene sequence of strain ID06-379 (1475 nt). Phylogenetic trees were reconstructed by the neighbor-joining (Saitou and Nei, 1987), maximum-likelihood (Felsenstein, 1981) and maximum-parsimony (Fitch, 1971) algorithms by using the MEGA 5.0 program (Tamura et al., 2011). The resultant tree topologies were evaluated by bootstrap analysis (Felsenstein, 1985) based on 1000 replicates.

\section{Phenotypic characterisation of mannanolytic- actinomycetes}

In order to determine colony appearance, strain ID06-379 was grown on yeast extract - malt extract (ISP-2) agar media at $30{ }^{\circ} \mathrm{C}$ for 7 days. Morphological features were observed by using a light microscope (BX-51; Olympus) and scanning electron microscope (JSM-5400; JEOL). The strain was grown on $\mathrm{HV}$ agar at $28{ }^{\circ} \mathrm{C}$ for 2 weeks samples for SEM observation were prepared using the protocol of Tamura et al. (1994). Other physiological and biochemical tests were performed using API ZYM, API Coryne and API $50 \mathrm{CH}$ systems (bioMérieux) according to the manufacturer's instructions.

\section{Chemotaxonomic analysis}

Cell material for the chemotaxonomic analyses was obtained by growing the strain in trypticase-soy broth (Difco) on a rotary shaker for 48 hand $100 \mathrm{rpm}$ at $28^{\circ} \mathrm{C}$. The cells were harvested by centrifugation, washed twice with distilled water and freeze-dried. Amino acids and the isomers in cell-wall hydrolysates, cell-wall sugars, isoprenoid quinones were determined according to the methods described by Hamada et al. (2012) using LC mass spectroscopy. Polar lipids were extracted from 100 mg dry cells, purified using the method described by Minnikin et al. (1975) and analysed by TLC using chloroform/methanol/water $(65: 25: 4$, by vol.) in the first direction and chloroform/acetic acid/methanol/water (80 : $18: 12: 5$, by vol.) in the second. For fatty acid methyl ester analysis, strain ID06-379 was cultured on tryptic soy agar (Difco) for $24 \mathrm{~h}$ at $28{ }^{\circ} \mathrm{C}$. Cellular fatty acid methyl esters were analysed by GC $(6890 \mathrm{~N}$; Agilent Technologies) according to the standard protocol of the Sherlock Microbial Identification System (Sasser, 1990) with Sherlock MIDI software (version 4.0) and a TSBA database (version 4.0). Genomic DNA for determination of the $\mathrm{G}+\mathrm{C}$ content was prepared according to the method of Saito and Miura (1963) and was determined by enzymatic hydrolysis of DNA followed by reverse-phase HPLC, as described by Tamura et al. (1994).

\section{RESULTS AND DISCUSSIONS}

\section{Selection of mannanase-producing actinomycetes}

Based on the isolation sources, most of the isolates used in this study were isolated from soils. About $15 \%$ of tested isolates were able to degrade LBG, as indicated by the formation of a clear zone around the growing colonies, and measured as CZI (Figure 1).

From the 337 actinomycetes isolates screened, 49 isolates formed CZI between $>1$ to $>5$ on LBG media. Radial diffusion of enzyme into the substrate incorporated in an agar gel produced zones of hydrolysis which can be visualised by staining non-degraded substrate with Congo red dye (Carder, 1986). Colonies producing mannanase showed clear zones against red colour of non-hydrolysed medium.

Among the 49 isolates which showed high mannanase activity, most were isolated from soil at Kutai and Sungai Wain located in Kalimantan Island, which consists of tropical rainforests, and is marked by dense forests, valleys and rivers. A large area of the district is covered by green forests, which are rich in lignocellulosic materials derived from the thick vegetation of Dipterocarpaceae plants. Naturally, these fertile soils would have a rich assemblage of actinomycetes.

It has been observed that the environment of the soil, such as temperature, humidity, and diversity of the plants species grown on forest soil, influence the growth rate and diversity of microorganisms. The temperature between $27-$ $29{ }^{\circ} \mathrm{C}$ and humidity around $66-88 \%$ at the sampling sites (Table 1) supports an abundant of microorganisms in that area. Tropical rainforests have abundant lignocellulosic material as a substrate for mannanolytic microorganisms. This condition is supposed to be an optimal condition for the growth of mannanolytic actinomycetes, taking part in the degradation of lignocellulosic material and responsible for the cycling of organic compounds. Soil microorganisms are vital for the continuing cycling of nutrients and for driving above-ground ecosystems (Ovreas, 2000).

Eight isolates which shown high mannanase activity (Nonomuraea sp. ID06-0379 and Streptomyces sp. ID070328, ID07-0332, ID07-0338, ID07-0365, ID07-0459, ID07-0463 and ID07-0496) were chosen for CZI screening test, which was about $3-<5$. A CZI higher than 
1.50 was considered to be a potential producer of mannanases (Florencio et al., 2012). The enzymatic index can be used as a simple and rapid methodology to select strains with the ability to produce enzymes. The reproducibility of the 8 isolates was conducted by reanalysing them using the same method. One isolate, Nonomuraeasp. ID06-379 was then chosen for indicate the study because it has high activity to degrade LBG substrate $(\mathrm{CZI}=6.48)$. This is based on the selection by Nonomuraea sp. strain ID06-0379, a rare actinomycetes, which is capable of producing mannanase enzyme with sufficiently high activity. Strain ID6-0379 was obtained from soil in Kutai National Park, using sodium dodecyl sulphate-yeast extract medium (Widyastuti and Ando, 2009).

\section{Enzyme production under submerged fermentation with various concentration of palm kernel cake (PKC) as substrate}

The substrate concentration plays an important role in enzyme production and activity. In this study, we employed the palm kernel cake at various concentrations under submerged fermentation. Mannanase production from strain ID06-0379 in submerged fermentation using PKC as a substrate was increased by substrate concentration from 1,5 and $10 \%$ from 1 to 5 day of incubation. The highest mannanase activity obtained was $4.40 \mathrm{U} / \mathrm{mL}$ at $5 \%$ PKC concentration (Figure 2) after 5 days of incubation; this might be due to the high concentration of substrate, which will influence the maximum medium component and oxygen transfer rate. The activity decreased after 5 days of incubation. These phenomena are due to the production of mannanase as a primary metabolite, which was produced by the degradation of carbon sources such as palm kernel cake for the development of biomass during the growth phase.
Bhoria et al. (2009) reported that Streptomyces sp. PG-08-3 isolated from sand produced high yield mannanase enzyme without using an expensive material for fermentation medium. The microbe achieved the mannanase activity of $15 \mathrm{U} / \mathrm{mL}$ when grown in minimal media containing $0.5 \%$ guar gum as a sole carbon source and a mannanase activity of $33 \mathrm{U} / \mathrm{mL}$ when grown in media containing soybean meals as a nitrogen source in submerge fermentation. Chuan et al. (2006) reported that $\beta$-mannanase produced by $B$. subtilis in a submerged fermentation system was recorded at $8 \mathrm{U} / \mathrm{mL}$, while done in the SSF system it was recorded achieved as high as $230 \mathrm{U} / \mathrm{g}$ dry PKC. Azis et al. (2008) also reported that submerged fermentation of PKC using Aspergillus niger FTCC 5003 resulted in a maximum mannanase activity of $104 \mathrm{U} / \mathrm{mL}$ following 8 days of fermentation.

Mannanolytic bacteria Geobacillus stearothermophilus L-07 (Sumardi et al., 2005), was reported to produce extracellular $\beta$-1,4-mannanases with the highest $\beta$ mannanase activity $(0.52 \mathrm{U} / \mathrm{mL})$ in culture medium containing locust bean gum as the best for producing

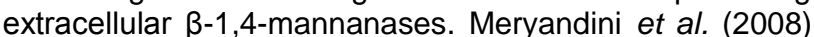
also reported an Indonesian actinomycetes identified as Streptomyces costarianus 451-3 isolated from Kalimantan, which has mannanolytic activity in the media containing $0.5 \%$ locust bean gum with the highest activity as $0.179 \mathrm{nkat} / \mathrm{mL}$, and $0.051 \mathrm{nkat} / \mathrm{mL}$ on the medium containing copra $0.5 \%$. Yopi et al. (2006) reported that hydrolysis using Streptomyces lipmanii and Kitasatospora $\mathrm{sp}$. that both isolates have the potential to produce mannanase with a mannanase activity of $0.032 \mathrm{U} / \mathrm{mL}$ and $0.133 \mathrm{U} / \mathrm{mL}$, respectively.

This result showed that although mannanase enzyme produced from Nonomuraea sp. strain ID06-379 had a lower enzyme activity compared with mannanase produced from fungi, and compared with among other mannanolytic bacteria were reported, this enzyme have a good activity.

\section{Clear Zone Index}

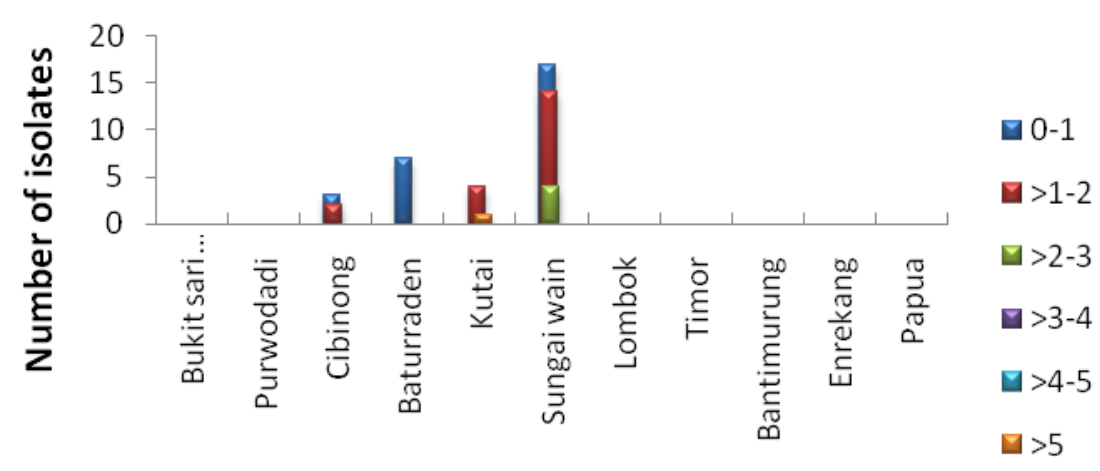

Sampling site

Figure 1: Index mannanolytic from screened actinomycetes. 
Table 1: Geographical position and regional climate characteristics.

\begin{tabular}{|c|c|c|c|c|c|c|c|c|c|c|c|}
\hline \multirow{2}{*}{$\begin{array}{l}\text { Sampling } \\
\text { site }\end{array}$} & \multicolumn{2}{|c|}{ Source } & \multicolumn{3}{|c|}{ Latitude } & \multicolumn{3}{|c|}{ Longitude } & \multirow{2}{*}{$\begin{array}{l}\text { Altitude } \\
\text { (m) }\end{array}$} & \multirow[t]{2}{*}{$\begin{array}{c}\text { Temperature } \\
\left({ }^{\circ} \mathrm{C}\right)\end{array}$} & \multirow[t]{2}{*}{ Environment } \\
\hline & Soil & $\begin{array}{l}\text { Leaf } \\
\text { litter }\end{array}$ & \multicolumn{3}{|c|}{$E / W$} & \multicolumn{3}{|c|}{$\mathrm{N} / \mathrm{S}$} & & & \\
\hline Purwodadi & 1 & & $E$ & 112 & 44 & $S$ & 07 & 48 & $290-300$ & $31-32.4$ & $\begin{array}{l}\text { Botanical } \\
\text { garden }\end{array}$ \\
\hline $\begin{array}{l}\text { Bukit sari } \\
\text { Jambi }\end{array}$ & 1 & & $E$ & 102 & 47 & $S$ & 01 & 34 & $60-70$ & $30.7-34.3$ & Tropical forest \\
\hline Cibinong & 10 & & $E$ & 106 & 50 & $S$ & 06 & 29 & $161-170$ & $31.1-32$ & Dry land \\
\hline Enrekang & 2 & & $E$ & 119 & 45 & $S$ & 03 & 28 & $626-796$ & $24-29$ & Burnt forest \\
\hline Timor & 7 & & $E$ & 123 & 49 & S & 10 & 15 & $25-562$ & $24.7-34.7$ & $\begin{array}{l}\text { Dry land } \\
\text { savanna }\end{array}$ \\
\hline Kutai & 32 & & $E$ & 117 & 27 & $\mathrm{~N}$ & 0 & 31 & $26-94$ & 27.3-29 & Tropical \\
\hline Lombok & 13 & & $E$ & 116 & 04 & S & 08 & 24 & $0.0-177$ & $28-33.7$ & Dry land \\
\hline Sungai Wain & 83 & 41 & $E$ & 116 & 51 & S & 01 & 08 & $40-50$ & $28-30$ & Tropical \\
\hline Baturraden & 37 & 7 & $E$ & 109 & 12 & $\mathrm{~S}$ & 07 & 14 & $600-750$ & $20-30$ & Pine forest \\
\hline Bantimurung & 85 & & $E$ & 119 & 45 & $\mathrm{~S}$ & 04 & 54 & ND & ND & $\begin{array}{l}\text { Karst Cave } \\
\text { ecosystem }\end{array}$ \\
\hline $\begin{array}{l}\text { Grasberg } \\
\text { Papua }\end{array}$ & 18 & & $E$ & 137 & 07-13 & $\mathrm{S}$ & 04 & $03-08$ & $\begin{array}{l}1900- \\
4000\end{array}$ & $5-15$ & $\begin{array}{l}\text { Highland } \\
\text { mining area }\end{array}$ \\
\hline Total & 289 & 48 & & & & & & & & & \\
\hline
\end{tabular}

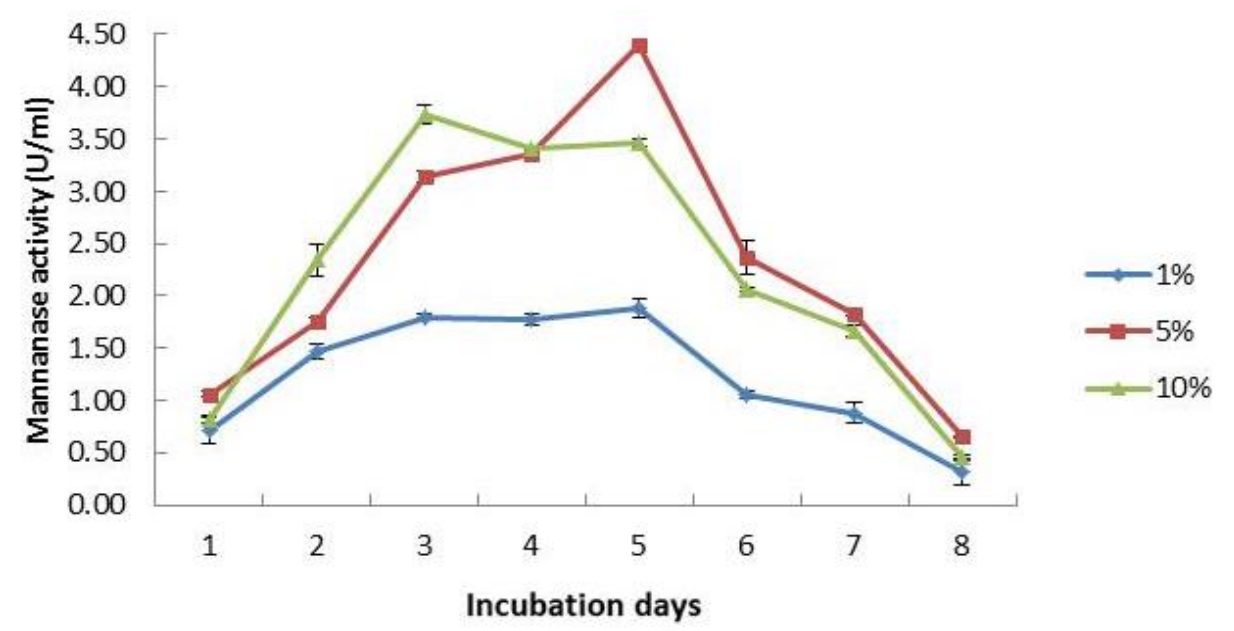

Figure 2: Mannanase activity of strain ID06-0379 on PKC substrate. Concentration of palm kernel cake $1 \%$ ( $\Delta$ triangles), $5 \%$ ( squares) and $10 \%$ concentration ( diamonds) in in the medium for mannanase production contained $0.4 \%$ yeast extract, $1 \%$ malt extract, and $0.4 \%$ locust bean gum ( $\mathrm{pH} 7.3)$. The culture was incubated at room temperature in a rotary shaker at $120 \mathrm{rpm}$.

\section{Phylogenetic analysis based on 16S rDNA}

Comparative analysis of $16 \mathrm{~S}$ rDNA sequences and phylogenetic relationships showed that strain ID06-379 grouped in a subclade with Nonomuraea jabiensis A4036T, supported by a bootstrap value of $68 \%$ in the neighbour joining analysis (Figure 3 ), with which it shared a $16 \mathrm{~S}$ rDNA sequence similarity of $99 \%$, this value corresponds to $6 \mathrm{nt}$ differences at 1475 locations. 16S rDNA nucleotide similarities values were ranging from $97 \%$ ( $N$. soli strain YIM 120770) to $99 \%\left(N\right.$. jabiensis A4036 ${ }^{\top}$ ) have been recorded for members of several validly described Nonomuraea type strain species. Phylogenetic analysis based on 16S rDNA sequence revealed that a closely related species for Nonomuraea sp. ID06-0379 was N. jabiensis A4036T. 


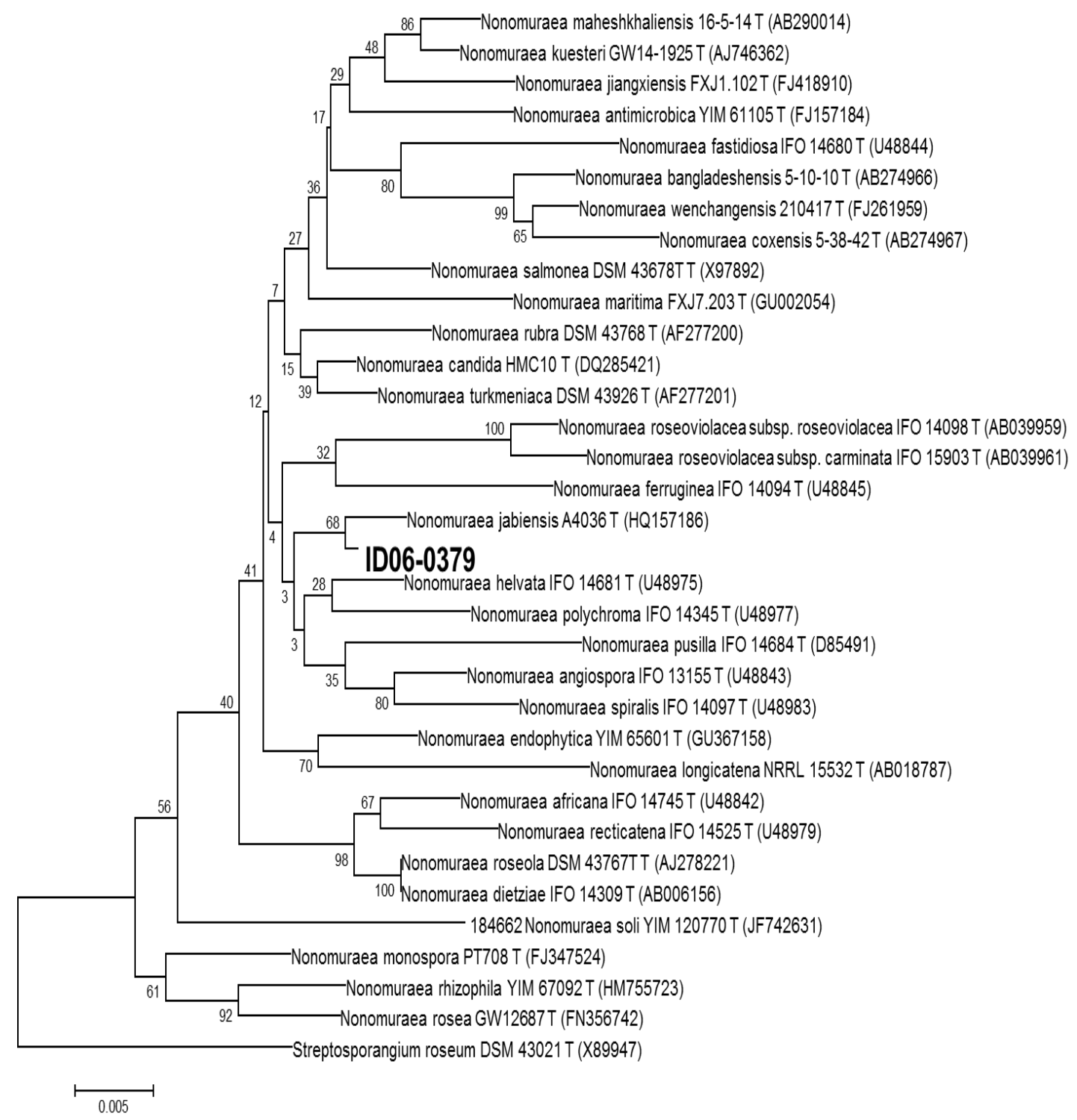

Figure 3: Neighbour-joining tree based on 16 rDNA sequences (1475 nt) showing the position of strain ID06-0379 amongst its phylogenetic neighbours. Streptosporangium roseum DSM $43021^{\top}$ was used as an outgroup. The tree was constructed using the neighbour-joining method and $\mathrm{K}_{\text {nuc }}$ values.

\section{Phenotypic characteristics of mannanolytic- actinomycetes strain ID06-0379}

Orange colour colonies appeared in the early stages of growth and became white orange in colour during the incubation period. Variability in the result of colony colour could be due to differences in colony age, variations in soil habitat and vegetation that could affect the species composition and their morphological and physiological characteristics (Saadoun et al., 2007). According to Lechevalier and Lechevalier (1980), the colour that appears in the actinomycetes colony result from
pigmentation.Colony of strain ID06-0379 produced a nearly round shape, rugous edges, and a surface that was hairy. The strain forms extensively branched, brownish orange substrate mycelia that bear white aerial hyphae on ISP 2. After 14 days of incubation at $28^{\circ} \mathrm{C}$, mycelium grown from vegetative branches formed mycelia fibres (Figure 4a); the strain formed extensively branched substrate mycelia and aerial hyphae that often formed spiral chains of spores with warty surfaces (Figure $4 b-d$ ), and spiral spore chains composed of warty surface spores were observed on the aerial mycelium (Figure 4d). 


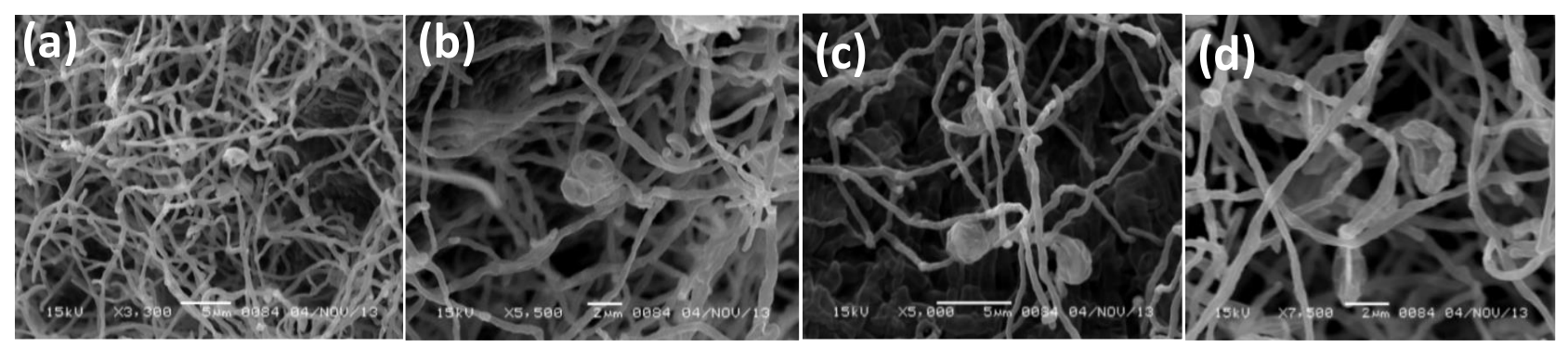

Figure 4: Scanning electron micrographs of Nonomuraea sp. strain ID06-0379 grown on HV agar at $28{ }^{\circ} \mathrm{C}$ for 2 weeks. The hooked/ curled spores chain morphology is clearly visible in (a) and (b). Spiral spores chains covered with sheath on aerial mycelium tips (c). Curled spores chains with warty surface (d). The size bar $2 \mu \mathrm{m}$ (b and d), $5 \mu \mathrm{m}(\mathrm{a}$ and c).

\section{Chemotaxonomic characterisation of strain ID06-379}

The whole-cell hydrolysate of the strain ID06-0379 contained meso-diaminopimelic acid (cell wall type III Lechevalier and Lechevalier, 1970) as the diagnostic diamino acid in the cell-wall peptidoglycan, and the wholecell sugars had mannose, glucose, ribose (major components), and madurose (Type $B$; madurose as a diagnostic sugar), with galactose as the minor component. The polar lipids of strain ID06-379 are of the PIV type, according to the phospholipid classification of Lechevalier et al. (1977), it were phosphatidylethanolamine (PE), diphosphatidylglycerol (DPG), phosphatidylinositol (PI), and hydroxy-phosphatidylethanolamine (OH-PE). Many members of the genus Nonomuraea have been shown to produce PE and OH-PE (Kämpfer et al., 2010). OH-PE has been found in N.longicatena (Chiba et al., 1999), $N$. bangladeshensis, $N$. coxensis (Ara et al., 2007a), and $N$. maheshkhaliensis (Ara et al., 2007b). This polar lipid profile is generally similar to those of recognized species of the genus Nonomuraea.

The quinone system found supports affiliation of strain ID06-379 to the genus Nonomuraea.The results of LCmass spectroscopy, demonstrate that strain sp. ID06-379 contained the menaquinone identified as MK-9. The predominant menaquinone of strain ID06-0379 was MK9(H4) (59.55\%); MK-9(H2) (24.3\%), MK-9(H0) (13.6\%) and MK-9(H6) (2.5\%) were also detected. This is essentially in accordance with the quinone profile reported for members of the genus (Quintana et al., 2003). MK-9 is the major menaquinone component in many Grampositive bacteria (Das et al., 1989) and was suggested to be the major menaquinone in the family Streptosporangiaceae.

The major cellular fatty acids of the strain ID06-379 were $\mathrm{C}_{16: 0}(31.47 \%)$, cis9- $\mathrm{C}_{16: 1}(15.23 \%)$ and iso- $\mathrm{C}_{16: 0}$ (10.84\%); minor amounts of cis9- $\mathrm{C}_{18: 1}(7.03 \%)$, cis9- $\mathrm{C}_{17: 1}$ (6.75\%), C14:0 (6.47\%), 10-methyl-C $16: 0$ (5.79\%), $\mathrm{C}_{15: 0}$ (3.11\%), 10-methyl- $\mathrm{C}_{17: 0}(2.83 \%), \mathrm{C}_{17: 0}(2.41 \%)$, iso- $\mathrm{C}_{15: 0}$ $(2.32 \%)$ and were also present. The $\mathrm{G}+\mathrm{C}$ content of the DNA was $71.7 \mathrm{~mol} \%$. The chemical and morphological properties of strain ID06-379 are consistent with its classification in the genus Nonomuraea (Tamura et al., 2000).
This results showed that on the bases of chemotaxonomic characterization, 16S rDNA sequence and phylogenetic tree analyses of strain ID06-379 was revealed that this characteristics are similar with the characteristics shown by the closest species $N$. jabiensis A4036T (Camas et al., 2013).

The differences in physiological characteristics between strain ID06-0379 with those of species of the genus Nonomuraea with validly published names are presented in Table 2. There were slightly physiological and biochemical features that differed between strain ID06-379 and N. jabiensis A4036 ${ }^{\top}$, such as differences in nitrate reduction, degradation of gelatin, starch, urea, and utilization of sole carbon sources. Strain ID06-379 and N. jabiensis $A 4036^{\top}$ have positive result in test for arbutin, and aesculin hydrolysis (Camas et al., 2013), but strain ID06-379 has negative result for urea hydrolysis and nitrate reduction. D-galactose, D-fructose, D-mannose, Dmannitol, arbutin, D-cellobiose, D-maltose, D-sucrose are used as sole carbon source, but D-xylose, maltose, Lxylose, L-sorbose, inulin and D-melezitose are not. This result also supported that strain ID06-0379 is belongs to species in the cluster of Nonomuraea species.

This study was the first report a new information that the species of Nonomuraea produced mannanase enzyme. It may need optimised media in enzyme production by using carbon or nitrogen sources due to different requirements by the isolate. Actinomycetes possess the potential to secrete a broad range of enzymes, which may be the results of natural selection of the microorganisms in order to survive in a competing environment (Jeffrey, 2008).

Mannanase enzyme produced by Nonomuraea sp. ID06-379 showed high activity, similar to that for Streptomyces costarianus 451-3, S. lipmanii and Kitasatospora sp. (Meryandini et al., 2008; Yopi et al., 2006) or other bacteria (Sumardi et al., 2005) but lower than the enzyme production of fungal mannanase from $A$. niger FTCC 5003 (Azis et al., 2008). This result showed that strain Nonomuraea sp. ID06-0379 has the potential to produce bacterial enzyme mannanase using agricultural waste such as palm kernel cake. 
Table 2: Phenotypic properties that differentiate strain ID06-0379 with those of species of the genus Nonomuraea with validly published names. Species: 1. ID06-379, 2. N. jabiensis A4036 ${ }^{\top}, 3$. N. angiospora DSM 43173 ${ }^{\top}, 4 . N^{2}$. candida

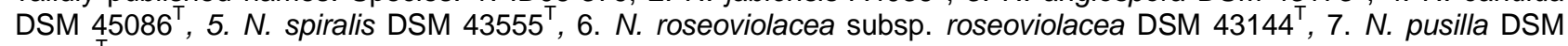
$43357^{\top}$.

\begin{tabular}{lccccccc}
\hline Biochemical test & 1 & 2 & 3 & 4 & 5 & 6 & 7 \\
\hline Nitrate reduction & - & + & - & + & + & + & + \\
Degradation of & & & & & & & \\
Gelatin hydrolysis & - & + & + & - & + & - & - \\
Starch & w & - & + & - & - & - & - \\
Growth on sole carbon source & & & & & & & \\
D-Xylose & - & + & + & + & + & + & - \\
Maltose & - & + & + & + & - & + & - \\
Sucrose & - & + & + & - & + & + & - \\
L-Xylose & - & + & + & + & + & + & - \\
D-Adonitol & w & + & + & - & - & + & + \\
D-Galactose & w & - & + & + & - & - & - \\
D-Fructose & w & + & + & + & - & + & - \\
D-Mannose & + & + & + & + & + & - & - \\
L-Sorbose & - & - & + & - & - & - & - \\
D-Mannitol & w & + & + & + & - & + & - \\
Arbutin & + & - & + & + & - & + & + \\
D-Cellobiose & w & - & - & + & - & + & + \\
D-Maltose & w & + & + & + & - & + & - \\
D-Sucrose & + & + & + & + & + & + & - \\
Inulin & - & + & + & + & - & + & - \\
D-Melezitose & - & + & - & - & + & + & - \\
\hline
\end{tabular}

Data are taken from Camas et al. (2013), Chiba et al. (1999), and Quintana et al. (2003). Symbols: +, positive; -, negative; W, weak.

\section{CONCLUSION}

From the 337 actinomycetes isolates screened, about $15 \%$ were capable of degrading LBG, as indicated by the formation of a clear zone around the growing colonies, which was measured as clear zone index (CZI). Phylogenetic analysis of $16 \mathrm{~S}$ rDNA sequence revealed that a closely related species for the strain ID06-0379 was N. jabiensis $\mathrm{A}_{4036^{\top}}$, which has $99 \%$ nucleotide similarity. On the basis of phenotypic and chemotaxonomic characters of the strain ID06-379, it was concluded that the strain was placed in the cluster of Nonomuraea species. This study was the first to report new information that the species of Nonomuraea produced mannanase enzyme; the best mannanase activity obtained was 4.40 $\mathrm{U} / \mathrm{mL}$ at $5 \%$ PKC concentration. These findings indicate that Nonomuraea sp. ID06-0379 was a potential isolate for the production of the bacterial enzyme mannanase using agricultural waste such as palm kernel cake and may contribute to the development and utilisation of biomass bioconversion processes.

\section{ACKNOWLEDGEMENTS}

We gratefully thank to Indonesian Institute of Sciences (LIPI), Indonesia and National Institute of Technology \& Evaluation (NITE). The authors are grateful to Dr. Tomohiko Tamura for excellent technical assistance, Dr. Yantyati Widyastuti and Dr. Puspita Lisdiyanti for kindly providing the actinomycetes strains, information data of the isolates, supervision in laboratory and corrections of manuscript. This study were fund supported by Joint Research Project between Indonesian Institute of Sciences (LIPI) and National Institute of Technology and Evaluation (NITE) of Japan: SATREPS Project for Development of Internationally Standardized Microbial Resource Center to Promote Life Science Research and Biotechnology, Competitive Research Grant from Indonesian Institute of Sciences and DIPA Grant from Indonesian Institute of Sciences.

\section{REFERENCES}

Ara, I., Kudo, T., Matsumoto, A., Takahashi Y., and Omura, S. (2007a). Nonomuraea bangladeshensis sp. nov.and Nonomuraea coxensis sp. nov. International Journal of Systematic and Evolutionary Microbiology 57, 1504-1509.

Ara, I., Kudo, T., Matsumoto, A., Takahashi, Y. and Omura, S. (2007b). Nonomuraea maheshkhaliensis sp. nov., a novel actinomycete isolated from mangrove rhizosphere mud. The Journal of General and Applied Microbiology 53, 159-166.

Azis, S. A., Ong, L. G. A., Hasan, M. A. and Karim, M. I. A. (2008). Process parameter optimisation of mannanase production from Aspergillus niger FTCC 5003 using palm kernel cake as carbon source. Asian Journal of Biochemistry 3(5), 297-307.

Béki, E., Nagy, I., Vanderleyden, J., JäGer, S., Kiss, L., Fu Lo,P. L., Hornok, L. and Kukolya, J. (2003). Cloning and heterologous expression of a-Dmannosidase (EC 3.2.1.25)-encoding gene from 
Thermobifida fusca TM51. Applied and Environmental Microbiology 69, 1944-1952.

Bhoria, P., Singh, G. and Hoondal, G. S. (2009). Optimization of mannanase production from Streptomyces sp. PG-08-03 in submerged fermentation. Bioresources 4(3), 1130-1138.

Bo, X., Duan, L., Tang, X., Li, J., Mu, Y., Yang, Y. and Huang, Z. (2009). Characterization of 6 Bacillus subtilis $\beta$-mannanases and their genes. African Journal of Biotechnology 8(18), 4316-4324.

Camas, M., Sazak, A., Spröer, C., Klenk, H.P., Cetin, D., Guven, K. and Sahin, N. (2013). Nonomuraea jabiensis sp.nov., isolated from arid soil. International Journal of Systematic and Evolutionary Microbiology 63 , 212-218.

Carder, J. H. (1986). Detection and quantification of cellulose by Congo red staining of substrates in a cupplate diffusion assay. Analytical Biochemistry 153(1), 75-79.

Chiba, S., Suzuki, M. and Ando, K. (1999).Taxonomic re-evaluation of 'Nocardiopsis' sp. K-252T (5NRRL 15532T): A proposal to transfer this strain to the genus Nonomuraea as Nonomuraea longicatena sp.nov. International Journal of Systematic Bacteriology 49, 1623-1630.

Chuan, C. H., Krishnaiah, K., Wong, C. M. and Janaun, J. (2006). Palm kernel cake as substrate for $\beta$ mannanase production by Bacillus subtilis ATCC3366 under submerged and solid state fermentations. Proceedings of the $1^{\text {st }}$ International Conference on Natural Resources Engineering \& Technology. 24-25 July 2006.Putrajaya, Malaysia pp.182-185.

Das, A., Hugenholtz, J., van Halbeek, H. and Ljungdahl, L. G. (1989). Structure and function of a menaquinone involved in electron transport in membranes of Clostridium thermoaceticum and Clostridium thermoautotrophicum. Journal of Bacteriology 171(11), 5823-5829.

Felsenstein, J. (1981). Evolutionary trees from DNA sequences: A maximum likelihood approach. Journal of Molecular Evolution 17, 368-376.

Felsenstein, J. (1985). Confidence limits on phylogenies: An approach using the bootstrap. Evolution 39, 738791.

Fitch, W. M. (1971). Toward defining the course of evolution: Minimum change for a specific tree topology. Systematic Zoology 20, 406-416.

Florencio, C., Couri, S. and Farinas, C.S. (2012). Correlation between agar plate screening and solidstate fermentation for the prediction of cellulase production by Trichoderma strains. Enzyme Research ArticleID 793708. doi:10.1155/2012/793708.

Frangos, T., Bullen, D., Bergquist, P. and Daniel, R. (1999). Hemicellulolytic and cellulolytic functions of the domains of a $\beta$-mannanase cloned from Caldicellosiruptor saccharolyticus. The International Journal of Biochemistry and Cell Biology 31(8), 853859.

Hamada, M., Yamamura, H., Komukai, C., Tamura, T., Suzuki, K. and Hayakawa, M. (2012). Luteimicrobium album sp. nov., a novel actinobacterium isolated from a lichen collected in Japan, and emended description of the genus Luteimicrobium. The Journal of Antibiotics 65, 427-431.

Jeffrey, L. S. H. (2008). Isolation, characterization and identification of actinomycetes from agriculture soils at Semongok, Sarawak. African Journal of Biotechnology 7(20), 3697-370.

Kämpfer, P., Busse, H. J., Tindall, B. J., Nimtz, M. and Grün-Wollny, I. (2010). Nonomuraea rosea sp. nov. International Journal of Systematic and Evolutionary Microbiology 60, 1118-1124.

Katrolia, P., Zhou, P., Zhang, P., Yan, Q., Li, Y., Jiang, Z. and $X \mathbf{U}, \mathbf{H}$. (2012). High level expression of a novel $\beta$-mannanase from Chaetomium sp. exhibiting efficient mannan hydrolysis. Carbohydrate Polymers 87, 480490.

Khanderparker, R., Numan, M. T. H., Mukherjee, B., Satwekar, A. and Bholse, N. B. (2008). Purification and characterisation of $\alpha$ - $L$-arabinofuranosidase from Arthrobacter sp. MTCC 5214 in solid state fermentation. Process Biochemistry 43, 707-712.

Kim, D. Y., Ham, S. J., Lee, H. J., Cho, H. Y., Kim, J. H., Kim, Y. J., Shin, D. H., Rhee, Y. H., Son, K. H. and Park, H. Y. (2011). Cloning and characterization of a modular GH5ß-1, 4-mannanase with high specific activity from the fibrolytic bacterium Cellulosimicrobium sp. strain HY-13. Bioresource Technology 102, 91859192.

Kim, O. S., Cho, Y. J., Lee, K., Yoon, S. H., Kim, M., Na, H., Park, S. C., Jeon, Y. S., Lee, J. H., Yi, H., Won, S. and Chun, J. (2012). Introducing EzTaxon-e: A prokaryotic 16S rRNA gene sequences database with phylotypes that represent uncultured species. International Journal of Systematic and Evolutionary Microbiology 62, 716-721.

Kumagai, Y., Kawakami, K., Mukaihara, T., Kimura, M. and Hatanaka, T. (2012). The structural analysis and the role of calcium binding site for thermal stability in mannanase. Biochimie 94, 2783-2790.

Lechevalier, M. P. and Lechevalier, H. A. (1970). Chemical composition as a criterion in the classification of aerobic actinomycetes. International Journal of Systematic Bacteriology 20, 435-443.

Lechevalier, M. P. and Lechevalier, H. A. (1980). The chemotaxonomy of actinomycetes. In: Actinomycete Taxonomy. Deitz, A. and Thayer, D.W. (eds.). Special Publication No. 6, SIM, Arlington. pp. 227-291.

Lisdiyanti, P., Tamura, T., Ratnakomala, S., Ridwan, R., Kartina, G., Lestari, Y., Ando, K. and Widyastuti, Y. (2012). Diversity of actinomycetes from soil samples collected from Lombok Island, Indonesia. Annales Bogorienses 16(1), 35-40.

Lynd, L. R., Weimer, P. J., van Zyl, W. H. and Pretorius, I. S. (2002). Microbial cellulose utilization: Fundamentals and biotechnology. Microbiology and Molecular Biology Reviews 66, 506-512.

Meenakshi, M., Singh, G., Bhalla, A., and Hoondal, G. S. (2010). Solid state fermentation and characterization of 
partially purified thermostable mannanase from Bacillus sp. MG-33. Bioresource 5(3), 1689-1701.

Meryandini, A., Ambarawati, D. and Rachmania, N. (2008). Characterization of mannanase from Streptomyces costaricanus 45I-3 (In Indonesian). Jurnal IImu Pertanian Indonesia 13(1), 1-6.

Miller, G. L. (1959). Use of dinitrosalicylic acid reagent for determination of reducing sugar. Analytical Chemistry 31(3), 426-428.

Minnikin, D. E., Alshamaony, L. and Goodfellow, M. (1975). Differentiation of Mycobacterium, Nocardia and related taxa by thin-layer chromatographic analysis of whole-organism methanolysates. Journal of General Microbiology 88, 200-204.

Ovreas, L. (2000). Population and community level approaches for analysing microbial diversity in natural environments. Ecology Letters 3, 236-251.

Quintana, E., Maldonado, L. and Goodfellow, M. (2003). Nonomurae aterrinata sp.nov., a novel soil actinomycete. Antonie van Leeuwenhoek 84, 1-6.

Saadoun, I., Rawashdeh, R., Dayeh, T., Ababneh, Q. and Mahasneh, A. (2007). Isolation, characterization and screening for fiber hydrolytic enzymes-producing Streptomyces of Jordanian soils. Biotechnology 6(1), 120-128.

Saito, H. and Miura, K. I. (1963). Preparation of transforming DNA by phenol treatment. Biochimica et Biophysica Acta 72, 619-629.

Saitou, N. and Nei, M. (1987). The neighbor-joining method: A new method for reconstructing phylogenetic trees. Molecular Biology and Evolution 4, 406-425.

Sasser, M. (1990). Identification of Bacteria by Gas Chromatography of Cellular Fatty Acids, MIDI Technical Note 101. MIDI Inc., Newark, DE, USA.

Shi, P., Yao, G., Cao, Y., Yang, P., Yuan, T., Huang, H., Bai, Y. and Yao, B. (2011). Cloning and characterization of a new $\beta$-mannosidase from Streptomyces sp. S27. Enzyme and Microbial Technology 49, 277-283.

Sumardi, Suwanto, A., Thenawidjaja, $\mathbf{M}$. and Purwadaria, T. (2005). Isolation and characterization of mannanolytic thermophilic bacteria from palm oil shell and their mannanase enzyme production properties. Biotropia 25, 1-10.

Tamura, K., Peterson, D., Peterson, N., Stecher, G., Nei, M. and Kumar, S. (2011). MEGA5: Molecular evolutionary genetics analysis using maximum likelihood, evolutionary distance, and maximum parsimony methods. Molecular Biology and Evolution 8, 2731-2739.

Tamura, T., Nakagaito, Y., Nishii, T., Hasegawa, T., Stackebrandt, E. and Yokota, A. (1994). A new genus of the order Actinomycetales Couchioplanes gen. nov., with descriptions of Couchioplanes caeruleus (Horan and Brodsky 1986) comb. nov.and Couchioplanes caeruleus subsp. azureus subsp. nov. International Journal of Systematic Bacteriology 44, 193-203.

Tamura, T., Suzuki, S. and Hatano, K. (2000). Acrocarpospora gen. nov., a new genus of the order
Actinomycetales. International Journal of Systematic and Evolutionary Microbiology 50, 1163-1171.

Thompson, J. D., Gibson, T. J., Plewniak, F., Jeanmougin, F. and Higgins, D. G. (1997). The CLUSTAL_X windows interface: Flexible strategies for multiple sequence alignment aided by quality analysis tools. Nucleic Acids Research 25, 4876-4882.

Wang, Y., Shi, P., Luo, H., Bai, Y., Huang, H., Yang, P., Xiong, H. and Yao, B. (2012). Cloning, overexpression and characterization of an alkali-tolerant endo- $\beta$-1, 4-mannanase from Penicilliumfreii F63. Journal of Bioscience and Bioengineering 113(6), 710-714.

Widyastuti, Y., and Ando, K. (2009). Taxonomic and ecological studies of actinomycetes in Indonesia. FINAL REPORT Joint Research Project between Indonesian Institute of Sciences (LIPI), representing the Government Research Centers (GRC) of the Republic of Indonesia and National Institute of Technology and Evaluation (NITE) of Japan. pp. 709711.

Wong, Y. P., Saw, H.Y., Janaun, J., Krishnaiah, K., Prabhakar, A. (2011). Solid-state fermentation of palm kernel cake with Aspergillus flavus in laterally aerated moving bed bioreactor. Applied Biochemistry and Biotechnology 164, 170-182.

Yopi, Purnawan, A., Thontowi, A., Hermansyah, H. and Wijanarko, A. (2006). Mannan preparation and crude mannanase from palm kernel cake (In Indonesian). Jurnal Teknologi 4 (XX), 312-319. 